\title{
The complex Robertsonian system of Dichroplus pratensis (Melanoplinae, Acrididae). I. Geographic distribution of fusion polymorphisms
}

\author{
CJ Bidau ${ }^{1, * * *}$, C Belinco ${ }^{2}, \mathrm{P} \mathrm{Mirol}^{3}, \mathrm{D}$ Tosto $^{3}$ \\ 1 Universidad Nacional de Misiones, Departamento de Genética, \\ Facultad de Ciencias Exactas, Químicas y Naturales, Félix de Azara 1552, \\ $6^{\circ}$ Piso, 3300 Posadas, Misiones, Argentina; \\ 2 Biological Sciences Center, Dept of Genetics and Cell Biology, \\ 1445 Gartner Ave, St Paul, MN, USA; \\ 3 Dept Ciencias Biológicas, Facultad de Ciencias Exactas y Naturales, \\ Universidad de Buenos Aires, Laboratorio de Genética, \\ 1428 Buenos Aires, Argentina
}

(Received 20 July 1990; accepted 17 June 1991)

Summary - A chromosomal survey was performed in Argentine natural populations of the South-American melanopline grasshopper Dichroplus pratensis Bruner (Acrididae). The cytogenetic study of samples from different populations revealed the existence of at least 7 distinct Robertsonian translocations which involve the $6 \mathrm{~L}$ (large) autosomes of the $2 n=20(Q) / 19\left(\sigma^{7}\right)$ all-telocentric standard karyotype. Some of the fusions thus share monobrachial homologies. The Robertsonian variation found in $D$ pratensis is discussed in relation to a model of chromosomal evolution for the species in which the changes in recombination patterns produced by the fusions are central.

centric fusion / polymorphism / polytypism / grasshopper

Résumé - Le système robertsonien complexe de Dichroplus pratensis (Melanoplinés, Acrididés). I. Distribution géographique des polymorphismes de fusion. Une enquête chromosomique a été réalisée sur des populations naturelles de sauterelles mélanoplines

* Member of the Carrera del Investigador Cientifico y Tecnológico (CONICET)

** Correspondence and reprints 
sud-américaines Dichroplus pratensis Bruner (Acrididés). L'étude cytogénétique d'échantillons en provenance de différentes populations a révélé l'existence d'au moins 7 translocations robertsoniennes distinctes qui impliquent les 6 grands autosomes du carotype standard entièrement télocentrique $2 n=20$ (femelles) $/ 19$ (mâles). Quelques-unes des fusions partagent ainsi des homologies monobrachiales. La variation robertsonienne trouvée chez $\mathrm{D}$ pratensis est discutée dans le contexte d'une évolution chromosomique où les changements des structures de recombinaison dus aux fusions jouent un rôle essentiel.

fusion centrique / polymorphisme / polytypisme / sauterelle

\section{INTRODUCTION}

The role of chromosomal change in speciation has been extensively discussed (White, 1978a,b, 1982; John, 1981; Mayr, 1982; Patton and Sherwood, 1983; Reig, 1984; Lande, 1985; Baker and Bickham, 1986; King, 1987; Sites and Moritz, 1987). Related species frequently have distinct karyotypes often assumed to be a consequence of a causal relationship between chromosomal rearrangements and speciation (White, 1978a). Karyotypic divergence may also be a by-product of speciation. This discussion is of interest since chromosomal models of speciation have been proposed (King, 1987; Sites and Moritz, 1987). Evidence for a role of chromosome change in speciation is far from clear, usually indirect and the critical properties of rearrangements have sometimes been overlooked or assumed without reliable data (John, 1981).

Chromosome polymorphisms and polytypisms allow the analysis of these issues. Centric fusions are involved in differences between species and races of animals and plants (White, 1973, 1978a; Jones, 1977). In Acridoid grasshoppers many species differences involve fixed fusions but polymorphisms and polytypisms are rare (White, 1973; Hewitt, 1979; Bidau and Hasson, 1984; Colombo, 1987; Bidau, 1989).

The neotropical genus Dichroplus is interesting because of its inter- and intraspecific chromosomal variability. Of 40 known species, 33 have been studied chromosomally and centric fusion is a major source of differentiation (Mesa et al, 1982). Some cases of intraspecific Robertsonian variation have been reported and in this respect Hewitt (1979) and John (1983) mention D pratensis Bruner, originally studied by Mesa (1956) and Sáez (1956). The cytogenetics of this species became very confused because of its morphologic similarity to $D$ obscurus which has an entirely different karyotype and geographic distribution (Bidau, 1984). The situation became clearer after Mesa's 1971 paper in which 2 fusion polymorphisms superimposed upon the standard karyotype were reported. Unfortunately, Mesa (1971) and Sáez and PérezMosquera (1970) called the different morphs "cytological races". This is an error which was carried over to John's (1983) paper.

The aim of our study was to establish whether the polymorphisms were present in other areas of the species distribution range or if they were limited to a hybrid zone between 2 authentic chromosomal races. The situation uncovered is more complex. 
Here we report the existence of several races differing in type and frequency of Robertsonian translocations.

\section{MATERIALS AND METHODS}

Adult grasshoppers of both sexes were collected between 1982 and 1989 at the localities shown in table I and figure 1. Testes dissected out in the field were fixed in 3:1 alcohol-acetic acid directly or after $15^{\prime}$ hypotonic treatment in $50 \%$ insect saline. Females were injected with $0.05 \%$ colchicine. Ovaries and gastric caeca were removed after $6-8 \mathrm{~h}$ and fixed after hypotonic treatment. Some males were colchicinised after biopsy for the removal of part of the testes. Cytological methods have already been described (Bidau, 1986). The standard karyotype was determined in males from Puerto Madryn and Gaiman (table I) through measurements of photographic enlargements and camera lucida drawings of Cmetaphases and late pachytene cells. The same procedure was followed for the identification of the different fusions. Banding methods did not prove useful for chromosome identification (see Results).

\section{RESULTS}

\section{The standard karyotype}

The standard chromosome complement is shared in principle by all sampled populations and it is unique within the genus (Mesa et al, 1982). A quantitative analysis was possible in 2 populations (Puerto Madryn and Gaiman) where the frequency of standards is high (table I). The karyotype comprises $19\left(\sigma^{\prime}\right)$ and 20 () telocentrics, 18 of which are autosomes (fig 2a). The latter include 6 large $\left(\mathrm{L}_{1}-\mathrm{L}_{6}\right)$ and 3 small $\left(\mathrm{S}_{7}-\mathrm{S}_{9}\right)$ chromosome pairs; the $\mathrm{X}$ is about the size of $\mathrm{L}_{4}$ (fig 2 ; table II). Relative lengths based on measures of C-metaphases and late pachytene bivalents are given in table II. $S_{7}$ is the megameric bivalent and has a heterochromatic interstitial block (fig $3 \mathrm{a}, \mathrm{b}) . \mathrm{S}_{8}$ carries a proximal NOR associated with a C-positive block (Bidau, 1986) (fig 3a,b). The only L-chromosome identifiable by $\mathrm{C}$-banding is $\mathrm{L}_{6}$, polymorphic for a distal heterochromatic block (fig $3 \mathrm{a}$ ).

Male meiosis is well characterised (Bidau, 1990). L-bivalents have a proximaldistal chiasma distribution while S-bivalents always form a single chiasma of variable localisation (Bidau, 1990).

\section{The fusions}

Seven Robertsonian translocations have been identified within the sampled area (figs 2-6; tables I-III). All 6 L-autosomes are involved. The 7 fusion chromosomes have centrometric indexes $>35.0$ (table III) ( $m$ according to Levan et al, 1964). They will be termed metacentric in this paper. The most symmetric fusion is $3 / 4$; the least symmetric, $1 / 6$. All populations but one are polymorphic for up to 4 fusions (table I). Populations polymorphic for 3 fusions exist that share the $3 / 4$ fusion but have the $1 / 6$ and $2 / 5$ fusions in one case (San Luis and La Pampa populations) 
Table I. Source and chromosomal features of samples of Dichroplus pratensis studied in this paper (see also fig 1 ).

\begin{tabular}{|c|c|c|c|c|c|c|c|}
\hline Locality $^{\mathrm{a}}$ & $C D^{\mathrm{b}}$ & $\sigma^{r}$ & $\mathrm{~N}^{\mathrm{c}}$ & $C F^{\mathrm{d}}$ & $K^{\mathrm{e}}$ & $S t^{\mathrm{f}}$ & $2 n^{g}$ \\
\hline 1 Tortuguitas & $\mathrm{Feb} / 82$ & 14 & - & $1 / 6 ; 3 / 4$ & 5 & 0 & $16-18$ \\
\hline 2 Las Flores & $\mathrm{Feb} / 83$ & 1 & - & $1 / 6 ; 3 / 4$ & 1 & 0 & 15 \\
\hline 3 Tandil 1 & Jan/85 & 18 & - & $1 / 6 ; 3 / 4$ & 4 & 0 & $15-17$ \\
\hline 4 Tandil 2 & Jan $/ 85$ & 15 & - & $1 / 6 ; 3 / 4$ & 6 & 0 & $15-17$ \\
\hline 5 Tandil 3 & Jan/85 & 2 & - & $1 / 6 ; 3 / 4$ & 1 & 0 & 15 \\
\hline 6 Balcarce & $\mathrm{Jan} / 85$ & 10 & - & $1 / 6 ; 3 / 4$ & 6 & 0 & $15-17$ \\
\hline 7 Necochea & $\mathrm{Jan} / 85$ & 5 & - & $1 / 6 ; 3 / 4$ & 4 & 0 & $15-17$ \\
\hline 8 Costa Bonita & Jan $/ 85$ & 3 & - & $1 / 6 ; 3 / 4$ & 2 & 0 & $16-17$ \\
\hline 9 Junin & Jan/84 & 2 & - & $1 / 6 ; 3 / 4$ & 2 & 0 & $17-18$ \\
\hline $10 \mathrm{Km} 784$ & Feb/83 & 20 & - & $1 / 6 ; 3 / 4 ; 5 / 6$ & 9 & 0.15 & $16-19$ \\
\hline 11 V Fortabat & $\operatorname{Jan} / 86$ & 1 & - & $1 / 6 ; 3 / 4$ & 1 & 0 & 16 \\
\hline $12 \mathrm{M}$ Hermoso & $\operatorname{Jan} / 83$ & 7 & - & $1 / 2 ; 3 / 4 ; 5 / 6$ & 4 & 0 & $13-15$ \\
\hline 13 El Cóndor & $\mathrm{Jan} / 83$ & 26 & - & $2 / 4 ; 5 / 6 ; 3 / 5 ?$ & 9 & 0.04 & $15-19$ \\
\hline 14 La Lobería & Jan/83 & 6 & - & $2 / 4 ; 5 / 6$ & 5 & 0 & $15-17$ \\
\hline $15 \mathrm{Km} 1058$ & Feb/83 & 2 & - & $2 / 4 ; 5 / 6$ & 1 & 0 & 17 \\
\hline 16 P Madryn & $\operatorname{Jan} / 83$ & 65 & - & $1 / 4 ; 5 / 6$ & 4 & 0.77 & $17-19$ \\
\hline 17 Gaiman & $\operatorname{Jan} / 83$ & 14 & - & $5 / 6$ & 2 & 0.93 & $18-19$ \\
\hline 18 La Florida & $\operatorname{Jan} / 84$ & 21 & - & $1 / 6 ; 2 / 5 ; 3 / 4$ & 12 & 0 & $13-16$ \\
\hline 19 Intihuasi & $\operatorname{Jan} / 84$ & 3 & - & $1 / 6 ; 2 / 5 ; 3 / 4$ & 3 & 0 & $14-17$ \\
\hline 20 Virorco & $\operatorname{Jan} / 84$ & 2 & - & $1 / 6 ; 2 / 5 ; 3 / 4$ & 2 & 0 & 14 \\
\hline 21 Don Tomás & $\operatorname{Jan} / 89$ & 26 & 4 & $1 / 6 ; 2 / 5 ; 3 / 4$ & 8 & 0 & $14-17$ \\
\hline 22 Utracán & $\operatorname{Jan} / 89$ & 16 & 8 & $1 / 6 ; 2 / 5 ; 3 / 4$ & 5 & 0 & $14-17$ \\
\hline 23 Parque Luro & $\operatorname{Jan} / 89$ & 44 & 29 & $1 / 6 ; 2 / 5 ; 3 / 4$ & 5 & 0 & $14-17$ \\
\hline 24 Gral Acha & Jan/89 & 16 & 6 & $1 / 6 ; 3 / 4$ & 7 & 0 & $15-19$ \\
\hline $25 \mathrm{~S}$ Ventana a & Feb/83 & 46 & - & $1 / 2 ; 3 / 4 ; 5 / 6 ; 1 / 6$ & 18 & 0 & $14-18$ \\
\hline $26 \mathrm{~S}$ Ventana $\mathrm{b}$ & $\operatorname{Jan} / 86$ & 19 & - & $1 / 2 ; 3 / 4 ; 5 / 6 ; 1 / 6$ & 13 & 0 & $13-18$ \\
\hline $27 \mathrm{~S}$ Ventana $\mathrm{c}$ & Feb/88 & 3 & - & $1 / 2 ; 3 / 4 ; 1 / 6$ & 2 & 0 & $15-16$ \\
\hline 28 El Atravesado & $\operatorname{Jan} / 86$ & 33 & - & $1 / 2 ; 3 / 4 ; 5 / 6 ; 1 / 6$ & 16 & 0 & $13-18$ \\
\hline 29 Saldungaray & $\operatorname{Jan} / 86$ & 16 & - & $1 / 6 ; 3 / 4 ; 5 / 6$ & 7 & 0 & $15-18$ \\
\hline 30 Z Peralta & $\operatorname{Jan} / 86$ & 16 & - & $1 / 2 ; 3 / 4 ; 5 / 6 ; 1 / 6$ & 12 & 0 & $15-18$ \\
\hline 31 Camping & $\mathrm{Jan} / 86$ & 12 & - & $1 / 2 ; 3 / 4 ; 5 / 6 ; 1 / 6$ & 9 & 0.08 & $15-19$ \\
\hline 32 Cerro l & $\operatorname{Jan} / 86$ & 18 & - & $1 / 2 ; 3 / 4 ; 5 / 6$ & 1 & 0 & 13 \\
\hline $33 \mathrm{C}$ Ventana a & $\mathrm{Jan} / 88$ & 17 & - & $1 / 2 ; 3 / 4 ; 5 / 6$ & 6 & 0 & $13-15$ \\
\hline $34 \mathrm{C}$ Ventana b & $\mathrm{Jan} / 88$ & 9 & - & $1 / 2 ; 3 / 4 ; 5 / 6$ & 4 & 0 & $13-18$ \\
\hline $35 \mathrm{C}$ Ventana $\mathrm{c}$ & $\operatorname{Jan} / 88$ & 8 & - & $1 / 6 ; 3 / 4$ & 5 & 0 & $15-18$ \\
\hline $36 \mathrm{C}$ Ventana $\mathrm{d}$ & $\operatorname{Jan} / 88$ & 1 & - & $1 / 2 ; 3 / 4 ; 5 / 6$ & 1 & 0 & 13 \\
\hline $\begin{array}{l}37 \text { Villa Ventana } \\
\text { area (several } \\
\text { localities) }\end{array}$ & $\begin{array}{l}\text { Jan/Feb } \\
87,88,89\end{array}$ & 363 & 75 & $1 / 2 ; 3 / 4 ; 5 / 6 ; 1 / 6$ & 30 & 0.002 & $13-20$ \\
\hline
\end{tabular}

The total number of males analysed is 900 and that of females $122 .{ }^{a}$ Localities 1-12 and 25-37 belong to Buenos Aires Province; 13-15, to Rio Negro Province; 16, 17, to Chubut Province; 18-20 to San Luis Province and 21-24, to La Pampa Province. ${ }^{\mathrm{b}} \mathrm{CD}$ : Collection date. ${ }^{\mathrm{c}} \mathrm{N}$ : number of males $\left(\mho^{\prime}\right)$ and females $(Q)$ studied cytologically. ${ }^{\mathrm{d}} \mathrm{CF}$ : centric fusions found in each sample. In sample 13, fusion $3 / 5$ appeared in one individual and its identification is doubtful. ${ }^{e} \mathrm{~K}$ : Number of karyomorphs found in the sample (regardless of sex-chromosome differences). ${ }^{\mathfrak{f}} \mathrm{St}$ : Frequency of standard (all telocentric) individuals in the sample. ${ }^{g} 2 \mathrm{n}$ : Range of diploid numbers found in males and females jointly. 


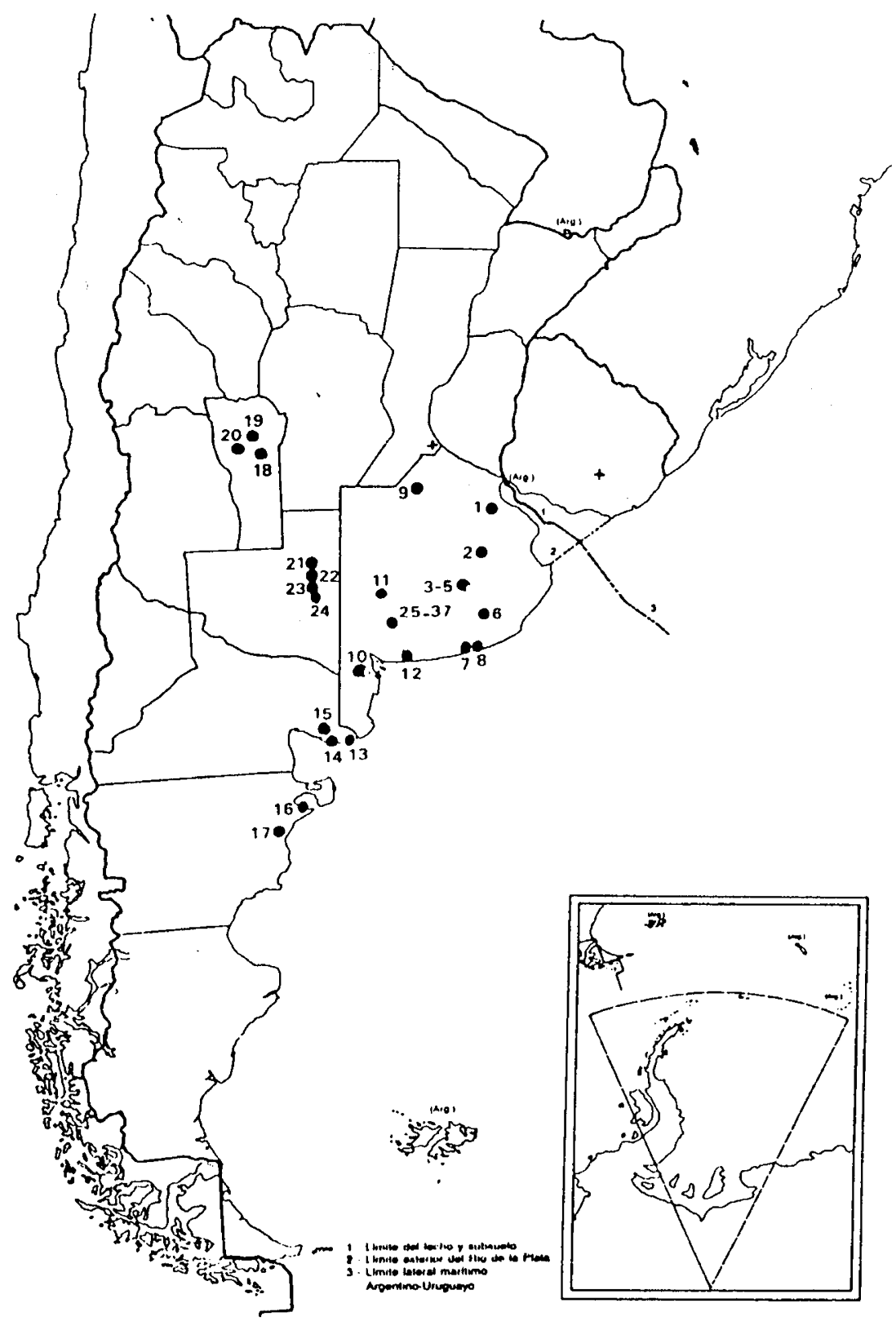

Fig 1. Localities of Dichroplus pratensis sampled $(\bullet)$. Also indicated is the source of specimens studied by Mesa (1971) in which the 1/6,3/4 fusion system probably occurs (+). References are given in table I. 
and the $1 / 2$ and 5/6 fusions in the other (Monte Hermoso and Sierra de la Ventana populations). Monobrachial homologies are evident in these examples which explain the populations polymorphic for more than 3 fusions that occur within hybrid zones (Bidau, 1991; Tosto and Bidau, 1991).

Table II. Mean relative lengths (MRL) of the telocentric autosomes of the standard karyotype of Dichroplus pratensis expressed as a percentage of the total haploid genome length.

\begin{tabular}{lcccccccccc}
\hline Chromosome & $\mathrm{L}_{1}$ & $\mathrm{~L}_{2}$ & $\mathrm{~L}_{3}$ & $\mathrm{~L}_{4}$ & $\mathrm{~L}_{5}$ & $\mathrm{~L}_{6}^{\mathrm{a}}$ & $\mathrm{S}_{7}^{\mathrm{b}}$ & $\mathrm{S}_{8}^{\mathrm{c}}$ & $\mathrm{S}_{9}$ & $\mathrm{X}$ \\
MRL & 17.9 & 14.7 & 13.7 & 12.3 & 10.9 & 9.8 & 3.3 & 3.1 & 2.8 & 11.5 \\
\hline
\end{tabular}

${ }^{a}$ Polymorphic for a distal C-positive block. ${ }^{b}$ Megameric bivalent. ${ }^{c}$ Carrier of the standard NOR.

Table III. Centromeric indexes ${ }^{\mathrm{a}}$ (CI) and arm ratios (AR) of 7 polymorphic centric fusions between $\mathrm{L}$ telocentric autosomes of Dichroplus pratensis.

\begin{tabular}{cccccccc}
\hline Fusion & $1 / 2$ & $3 / 4$ & $5 / 6$ & $1 / 6$ & $2 / 5$ & $1 / 4$ & $2 / 4$ \\
$\mathrm{CI} \pm \mathrm{SE} 46.2 \pm 0.5$ & $47.6 \pm 0.6$ & $46.6 \pm 0.4$ & $35.1 \pm 0.8$ & $41.6 \pm 0.4$ & $41.3 \pm 0.5$ & $45.4 \pm 0.6$ \\
$\mathrm{AR} \pm \mathrm{SE}$ & $0.86 \pm 0.02$ & $0.91 \pm 0.02$ & $0.87 \pm 0.02$ & $0.55 \pm 0.02$ & $0.73 \pm 0.02$ & $0.71 \pm 0.01$ & $0.83 \pm 0.02$ \\
\hline
\end{tabular}

${ }^{a}$ Centromeric index: (short arm length/total chromosome length) $\times 100 .{ }^{b}$ Arm ratio: short arm length/long arm length.

Polymorphism for a fusion implies 3 karyotypes: standard (st), structural heterozygote $(\mathrm{Het})$ and homozygote $(\mathrm{Hom})$. Thus populations polymorphic for 2 or 3 simple fusions will potentially show 9 and 27 karyotypes respectively. For example, all 9 karyotypes were found in the El Cóndor population, polymorphic for $2 / 4$ and $5 / 6$. Considering the 7 fusions, 60 different karyotypes are expected in each sex within the species. Since monobrachial homologies occur, further karyotypes are expected in hybrid zones (see below and Bidau, 1991). (2 types of B chromosomes also produce karyotype variation (Bidau, 1986, 1987).)

Meiotic behavior of Hets, Homs and hybrids has already been described. In Hets and Homs it is very regular as expected (despite low frequencies of nondisjunction in trivalents) (Bidau and Mirol, 1988; Bidau, 1990). Hybrids however, show a markedly abnormal meiotic behavior (Bidau, 1991). Nevertheless, a marked modification of the chiasma patterns occurs in all Hets and Homs: it mainly consists of a significant shift of chiasma positions to distal localisations in the chromosomes involved in the fusions, together with a reduction of cell mean chiasma frequency (Bidau, 1990). A more complex repatterning occurs in hybrids (Bidau and Fenocchio, in preparation).

\section{Frequency and distribution of the fusions}

The area sampled for fusions in Argentina, although large, represents but a limited picture of the potential situation in view of the wide distribution range of the species (Liebermann, 1963). 


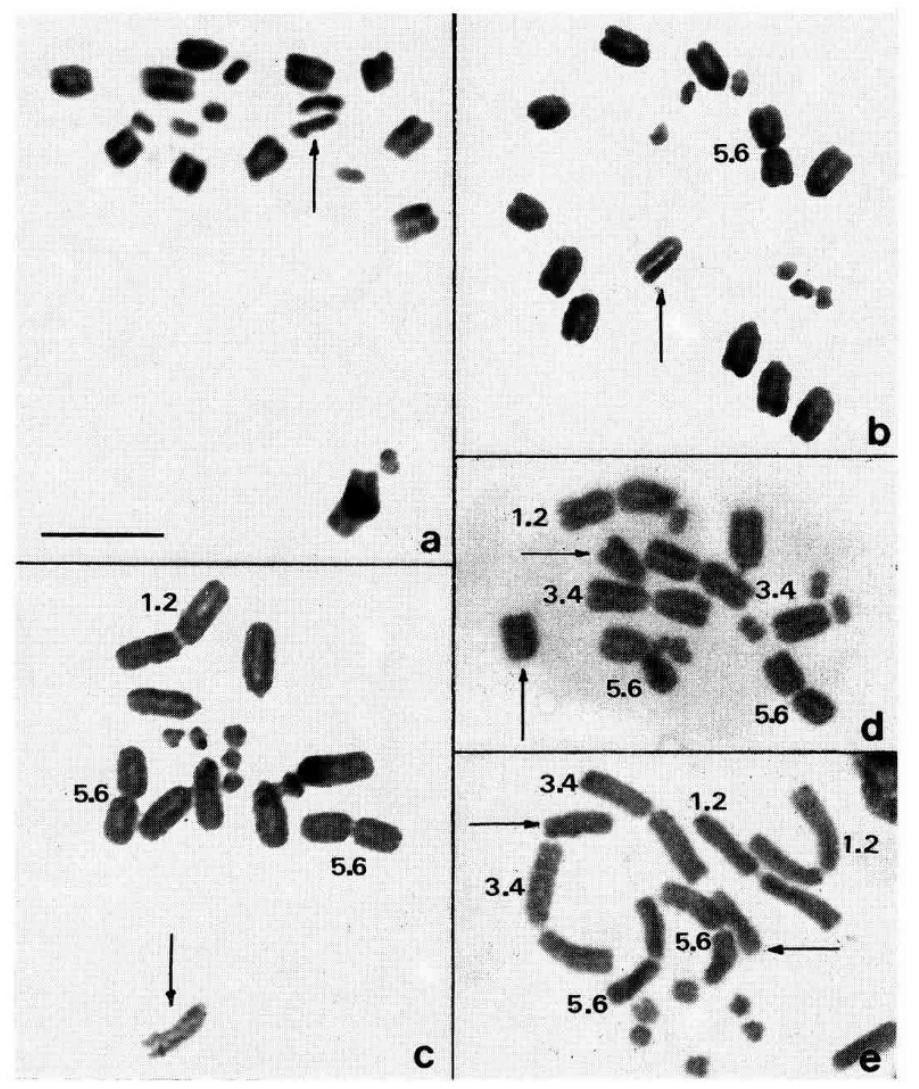

Fig 2. Male and female C-metaphases showing karyotypic variation in $D$ pratensis. a-c: Male. d,e: Female. a: Standard all-telocentric karyotype $(2 n=19)$. b: $5 / 6$ heterozygote $(2 n=18)$. c: $1 / 2$ heterozygote, $5 / 6$ homozygote $(2 n=16)$. d: $1 / 2$ heterozygote, $3 / 4$, $5 / 6$ homozygote $(2 n=15)$. e: $1 / 2,3 / 4,5 / 6$ homozygote $(2 n=14)$. Arrows point to $\mathrm{X}$ chromosomes. Bar $=10 \mu \mathrm{m}$.

No strict geographic pattern emerges from the study of the karyotyped populations but some regularities are apparent. Fusions $3 / 4$ and $1 / 6$ are widespread in the northern sampled area while fusion $2 / 5$, although associated with the former, has been found only in the westernmost part of the area. Futhermore, $2 / 5$ is frequent at San Luis but decreases southwards, disappearing at Gral Acha (La Pampa) (table IV). Fusion 1/2 seems limited to Sierra de la Ventana and Monte Hermoso. 5/6 occurs in the southern range of the species and $1 / 4$ and $2 / 4$ are limited to coastal populations of Río Negro and Chubut provinces respectively. One individual from El Cóndor probably carried an eight fusion, $3 / 5$. 
६
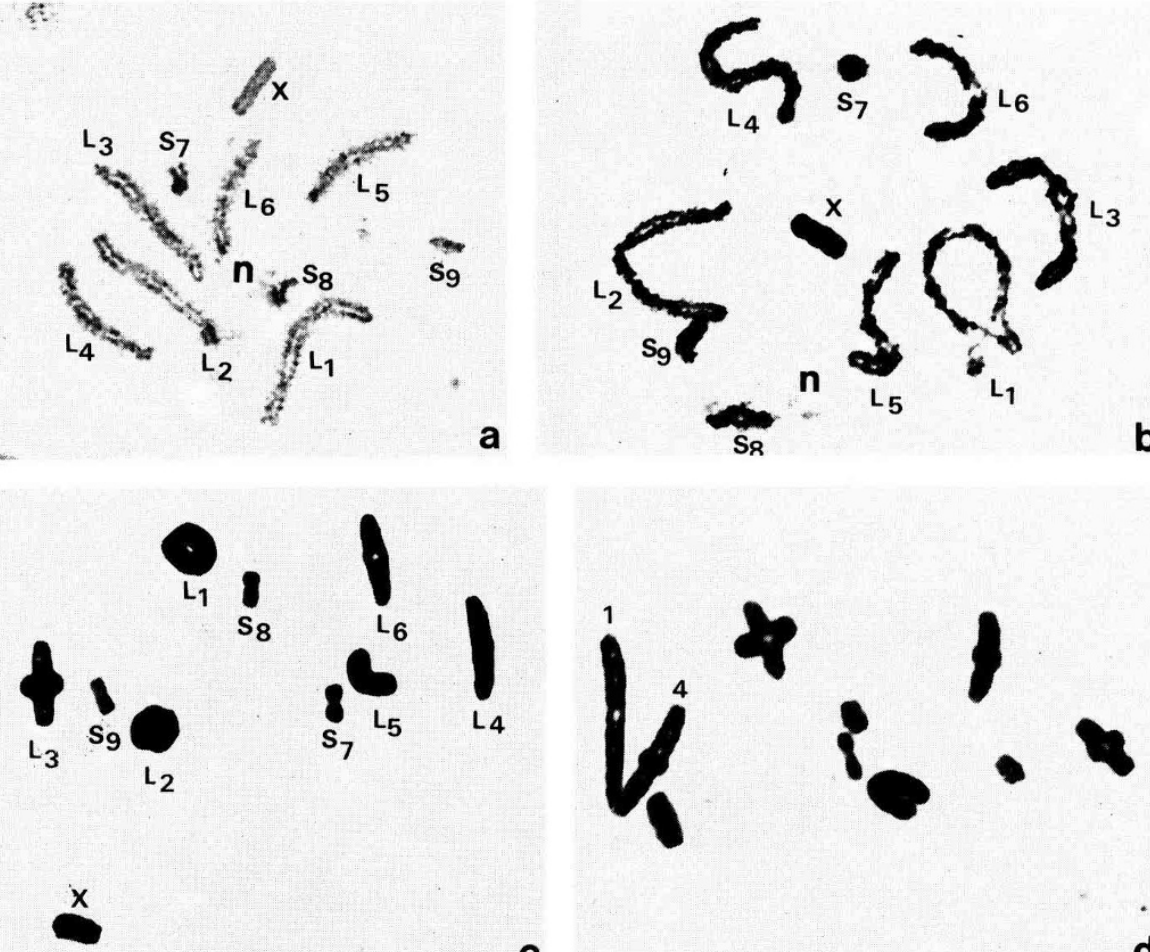

C

d
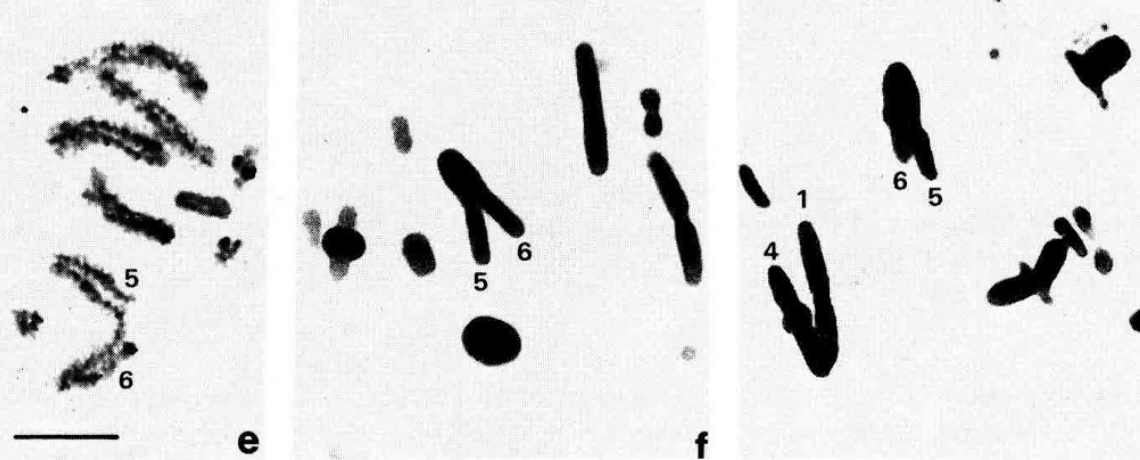

$\mathbf{f}$

g

Fig 3. Male meiosis in individuals from Puerto Madryn. a-c: Standard karyotype. d-g: Fusion variants. a: Pachytene. b: diplotene. c: MI (note proximal-distal chiasma distribution). d: MI; $1 / 4$ heterozygote. e: Pachytene; 5/6 heterozygote (note 5-5.6-6 trivalent). $\mathrm{f}: \mathrm{MI} ; 5 / 6$ heterozygote. g: $\mathrm{MI} ; 1 / 4,5 / 6$ heterozygote. Bar $=10 \mu \mathrm{m}$. 

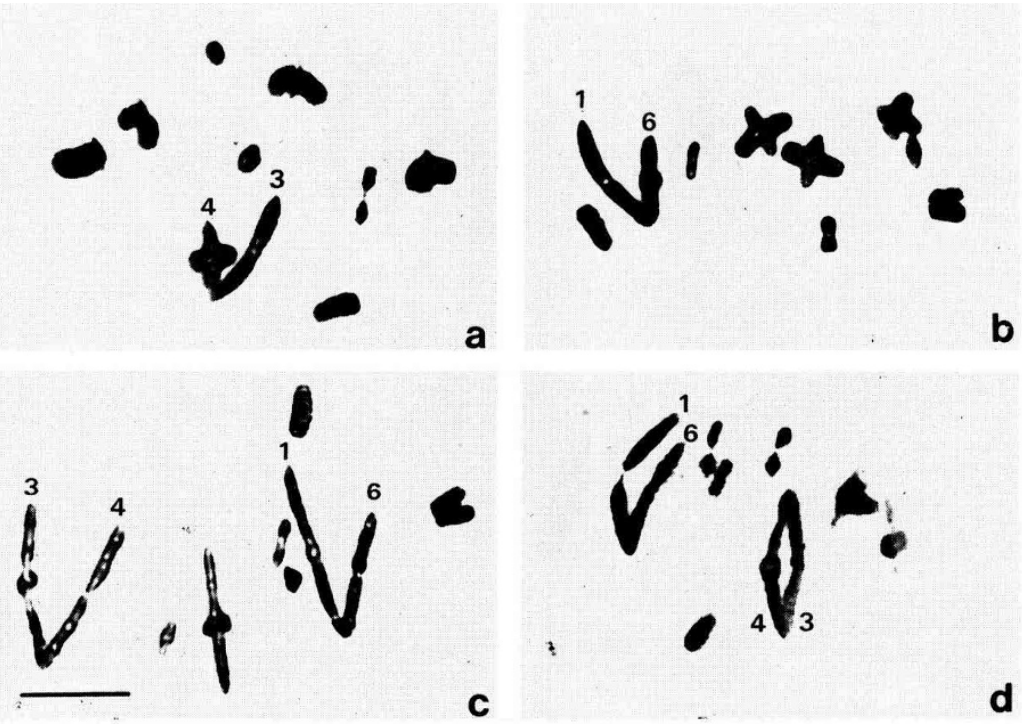

Fig 4 . The $1 / 6,3 / 4$ fusion system of $D$ pratensis. Male MI of Tortuguitas individuals. a: $3 / 4$ heterozygote. b: $1 / 6$ heterozygote. c: $1 / 6,3 / 4$ heterozygote. d: $1 / 6$ heterozygote, $3 / 4$ homozygote. Bar $=10 \mu \mathrm{m}$.

Within the same fusion system, frequencies of each fusion may vary widely as in the $2 / 5$ case already mentioned. Nevertheless, all polymorphisms fit the HardyWeinberg equilibrium since no departures from the expected values were found (Bidau, 1984; Tosto and Bidau, 1991).

\section{DISCUSSION}

Chromosomal polymorphism is rather frequent in natural populations but its role in evolution is debatable. This has been thorougly studied in Drosophila (Brussard, 1984; Sperlich and Pfriem, 1986). When analysing the fate of chromosomal rearrangements in natural populations, their potential involvement in speciation is relevant (King, 1987; Sites and Moritz, 1987). Second, chromosome polymorphisms common within a species are frequently not of the type of rearrangement determining interspecific differences (Bidau, 1989). Third, the mechanical and genetic properties of chromosome rearrangements must be considered to establish their role in adaptive and/or speciation processes. Last, the distribution of polymorphisms may fit an ordered pattern such as the central-marginal model (Brussard, 1984), an unknown pattern or no pattern at all.

Centric fusions occur as spontaneous mutants, polymorphisms, polytypisms and interspecific differences in many organisms (Jones, 1977; White, 1978a; Hewitt, 

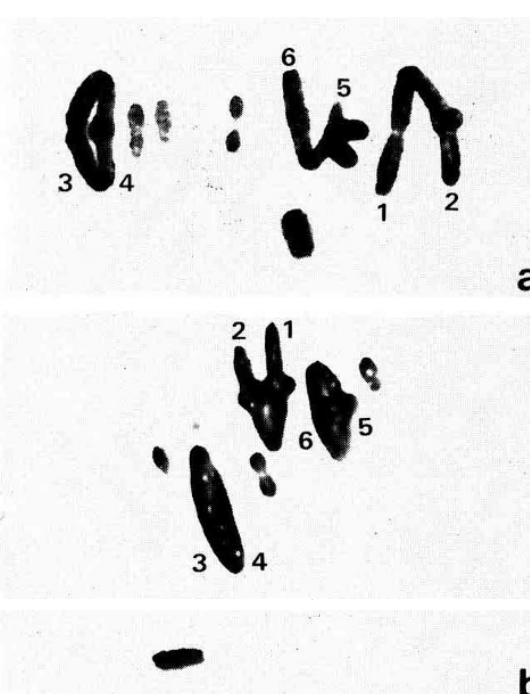

a

b

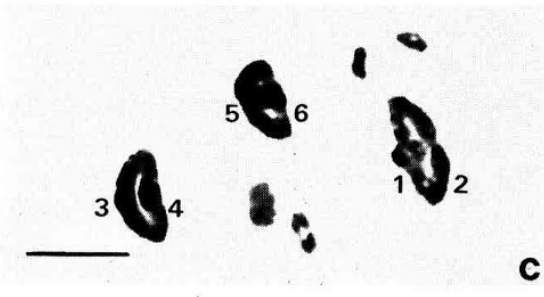

Fig 5. The $1 / 2,3 / 4,5 / 6$ fusion system of $D$ pratensis. Male MI of Monte Hermoso individuals. a: $1 / 2,5 / 6$ heterozygote, $3 / 4$ homozygote. b: $1 / 2$ heterozygote, $3 / 4,5 / 6$ homozygote. c: $1 / 2,3 / 4,5 / 6$ homozygote. $\mathrm{Bar}=10 \mu \mathrm{m}$.

1979 ; John, 1983; Patton and Sherwood, 1983; Bidau and Mirol, 1988; Redi and Capanna, 1988; Searle, 1988; Searle et al, 1990). Single fusion polymorphisms are more common than multiple ones, restricted to a few known cases (eg Koop et al, 1983; Tichy and Vucak, 1987; Nachman and Myers, 1989; Searle et al, 1990). Polytypic variation includes some notable and well studied examples (Capanna, 1982; Bogdanov et al, 1986; Searle et al, 1990) and interspecific differences are quite common (White, 1978a).

In the Acrididae, centric fusion has been a dominant form of change during the evolution of the group (John and Hewitt, 1968; John and Freeman, 1975; Hewitt, $1979 ;$ John, 1983). It is thus puzzling that very few cases of polymorphisms and polytypisms have been reported (Hewitt, 1979; John, 1983). Only 2 cases of single fusion polymorphism were previously analysed on a population basis (Hewitt and Schroeter, 1968; Bidau and Hasson, 1984; Colombo, 1987). 


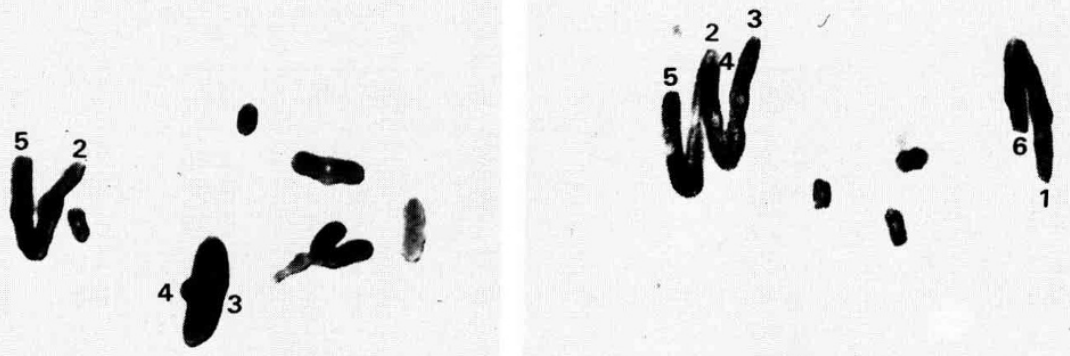

a

b

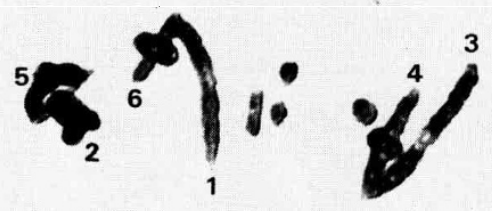

C
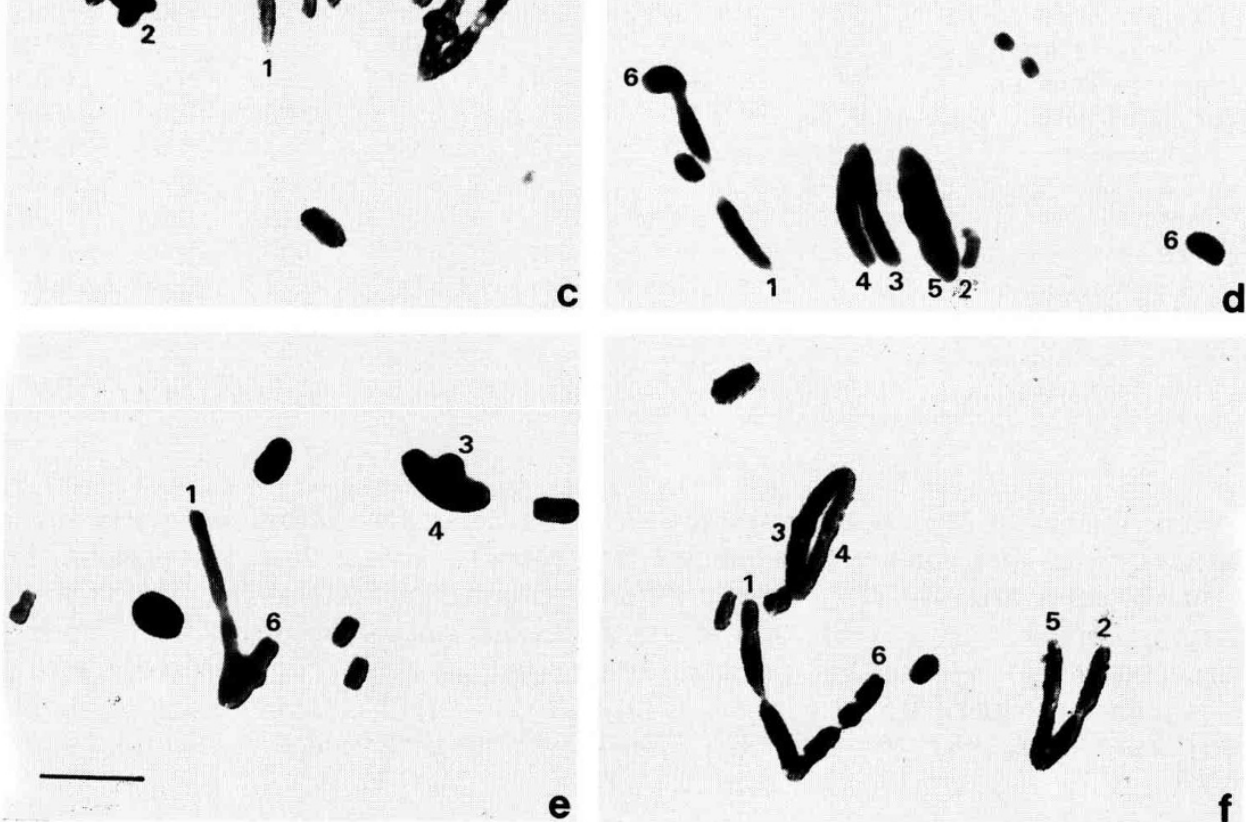

e

Fig 6. The $1 / 6,2 / 5,3 / 4$ fusion system of $D$ pratensis. Male MI of San Luis individuals. a: $2 / 5$ heterozygote, $3 / 4$ homozygote. b: $1 / 6,2 / 5,3 / 4$ heterozygote. c: $1 / 6,3 / 4$ heterozygote, $2 / 5$ homozygote. d: $1 / 6,3 / 4$ heterozygote, $2 / 5$ homozygote (note chiasma failure in arm 6). e: $1 / 6$ heterozygote, $3 / 4$ homozygote. $\mathrm{f}: 1 / 6,2 / 5$ heterozygote, $3 / 4$ homozygote. Bar $=10 \mu \mathrm{m}$. 
Table IV. Frequencies of 7 fusions of Dichroplus pratensis in different natural populations.

\begin{tabular}{|c|c|c|c|c|c|c|c|}
\hline \multirow[t]{2}{*}{ Populalion } & \multicolumn{7}{|c|}{ Frequency of fusions } \\
\hline & $1 / 2$ & $3 / 4$ & $5 / 6$ & $1 / 4$ & $1 / 6$ & $2 / 4$ & $2 / 5$ \\
\hline Tortuguitas & 0.00 & 0.58 & 0.00 & 0.00 & 0.36 & 0.00 & 0.00 \\
\hline Tandil 1 & 0.00 & 0.86 & 0.00 & 0.00 & 0.94 & 0.00 & 0.00 \\
\hline Tandil 2 & 0.00 & 0.80 & 0.00 & 0.00 & 0.80 & 0.00 & 0.00 \\
\hline Balcarce & 0.00 & 0.70 & 0.00 & 0.00 & 0.80 & 0.00 & 0.00 \\
\hline Necochea & 0.00 & 0.60 & 0.00 & 0.00 & 1.00 & 0.00 & 0.00 \\
\hline Km 784 & 0.00 & 0.55 & 0.08 & 0.00 & 0.15 & 0.00 & 0.00 \\
\hline Monte Hermoso & 0.93 & 0.79 & 0.93 & 0.00 & 0.00 & 0.00 & 0.00 \\
\hline El Cóndor & 0.00 & 0.00 & 0.62 & 0.00 & 0.00 & 0.44 & 0.00 \\
\hline La Lobería & 0.00 & 0.00 & 0.75 & 0.00 & 0.00 & 0.67 & 0.00 \\
\hline Puerto Madryn & 0.00 & 0.00 & 0.05 & 0.08 & 0.00 & 0.00 & 0.00 \\
\hline Gaiman & 0.00 & 0.00 & 0.04 & 0.00 & 0.00 & 0.00 & 0.00 \\
\hline La Florida & 0.00 & 0.76 & 0.00 & 0.00 & 0.64 & 0.00 & 0.64 \\
\hline Don Tomás & 0.00 & 1.00 & 0.00 & 0.00 & 0.83 & 0.00 & 0.05 \\
\hline Etracán & 0.00 & 1.00 & 0.00 & 0.00 & 0.73 & 0.00 & 0.04 \\
\hline Parque Luro & 0.00 & 1.00 & 0.00 & 0.00 & 0.84 & 0.00 & 0.03 \\
\hline General Acha & 0.00 & 0.70 & 0.00 & 0.00 & 0.70 & 0.00 & 0.00 \\
\hline Sa de la Ventana a & 0.25 & 0.84 & 0.27 & 0.00 & 0.27 & 0.00 & 0.00 \\
\hline Sa de la Ventana b & 0.24 & 0.84 & 0.47 & 0.00 & 0.24 & 0.00 & 0.00 \\
\hline El Atravesado & 0.41 & 0.91 & 0.58 & 0.00 & 0.09 & 0.00 & 0.00 \\
\hline Saldungaray & 0.00 & 0.59 & 0.00 & 0.00 & 0.66 & 0.00 & 0.00 \\
\hline Z Peralua & 0.13 & 0.69 & 0.28 & 0.00 & 0.22 & 0.00 & 0.00 \\
\hline Camping & 0.04 & 0.67 & 0.21 & 0.00 & 0.46 & 0.00 & 0.00 \\
\hline Cerro & 1.00 & 1.00 & 1.00 & 0.00 & 0.00 & 0.00 & 0.00 \\
\hline Cerro Ventana a & 0.91 & 0.97 & 0.85 & 0.00 & 0.00 & 0.00 & 0.00 \\
\hline Cerro Ventana b & 0.89 & 0.89 & 0.83 & 0.00 & 0.00 & 0.00 & 0.00 \\
\hline Cerro Ventana c & 0.00 & 0.81 & 0.00 & 0.00 & 0.67 & 0.00 & 0.00 \\
\hline Villa Ventana area & $0.00-1.00$ & $0.55-1.00$ & $0.00-1.00$ & 0.00 & $0.00-0.50$ & 0.00 & 0.00 \\
\hline
\end{tabular}

The fusions of $D$ pratensis probably arose independently in different parts of the species range and spread subsequently (see below). Nevertheless, the possibilities that the same arose several times in different populations or else that two or more fusions appeared as a result of a single mutation, cannot be discarded. There is circumstancial evidence that the same rearrangement can occur repeatedly within a population (Sperlich and Pfriem, 1986) and that rapid multiple rearrangements do occur (King, 1982; Peters, 1982). Thus karyotypic orthoselection (White, 1978a) need not depend on a slow sequential process.

Centric fusion is the dominant form of chromosome variation in $D$ pratensis (and within Dichroplus) apart from B chromosomes (Bidau, 1986, 1987). It is thus possible that $D$ pratensis chromosomes have a tendency to break non-randomly at the centromere, increasing the probability of fusions which could, depending on other factors (see below), become established as polymorphisms. Molecular mechanisms have been proposed to explain the high incidence of Robertsonian fusion in the mouse (Redi et al, 1986, 1990; Redi and Capanna, 1988) based on 
DNA sequence homology in pericentromeric areas of all chromosomes. These models could apply to $D$ pratensis as well.

With one exception, all multiple polymorphisms of $D$ pratensis fit the HardyWeinberg equilibrium (Tosto, 1989; Tosto and Bidau, 1991). Fixation of 3 fusions was only observed in one isolated populations (Bidau, 1989; Tosto and Bidau, 1991). Maintenance of such balanced polymorphisms is only possible if meiotic behaviour of trivalents in heterozygotes is regular (unless heterozygotes are positively heterotic despite loss of fertility due to meiotic misbehaviour). We have shown that all heterozygous fusions behave well at meiosis (Bidau and Mirol, 1988; Mirol and Bidau, 1991a) as demonstrated by their very low non-convergent orientation frequencies and production of abnormal sperm. However, aneuploidy and macrospermatid production increase with the number of heterozygous fusions (Bidau and Mirol, 1988) which could explain the higher frequencies of fusion metacentrics in populations with 3 fusions in order to minimise the frequencies of double and triple heterozygotes (Tosto, 1989; Tosto and Bidau, 1991). In comparable stable multiple polymorphisms such as those of the common shrew, heterozygotes do not have their fertility severely reduced (Searle, 1984, 1988; Garagna et al, 1989; Searle et al, 1990).

Stable meiotic behaviour is achieved by a repatterning of chiasma distribution of the fused chromosomes (Bidau, 1990; Mirol and Bidau, 1991b) which leads to the conclusion that fusions can affect intra- (and inter-) chromosomal recombination drastically. Thus they could serve to protect the integrity of coadapted supergenes and also allow for the maintenance of favourable linkage disequilibria. A rationale for the existence of the polymorphisms thus exists.

Each fusion system could become established because it protects a given set of coadapted supergenes adaptive to a given habitat (Bidau, 1989, 1990). Colonisation of a new environment may occur in the standard high recombination condition followed by adaptation and establishment of a particular fusion system (fig 7). This could explain the diversity of polymorphisms in relation to the wide ecological tolerance of the species. In this context it is worth recalling the "central-marginal" model. Although no clear pattern of distribution of polymorphisms emerges from the data (perhaps because only a part of the large distribution area of the species was sampled) 3 points are evident: 1 ), certain fusions occur only or are more frequent in certain areas; 2), frequency gradients for some fusions exist $(i e 2 / 5)$; and 3 ), the less polymorphic populations are those from eastern central Patagonia (PM and $G$ ) which are ecologically marginal since their habitat conditions are certainly rougher and population densities lower than in the rest; they thus share properties of marginal populations (Brussard, 1984).

Frequently, chromosomal differences between species are not of types characterising their common polymorphisms (ie John and Weissman, 1977; John et al, 1983; Sperlich and Pfriem, 1986). This applies to $D$ pratensis whose unique standard karyotype possibly derived through 2 tandem fusions from the basic Cryptossacci complement, but whose polymorphisms are essentially Robertsonian.

Centric fusions are candidates for the establisment of post-mating barriers (King, 1987; White, 1978) if conditions for the establishment of a balanced polymorphism are not met. Polymorphic fusions would thus have no impact on speciation. $D$ pratensis however, presents a complex situation: since the same telocentrics 


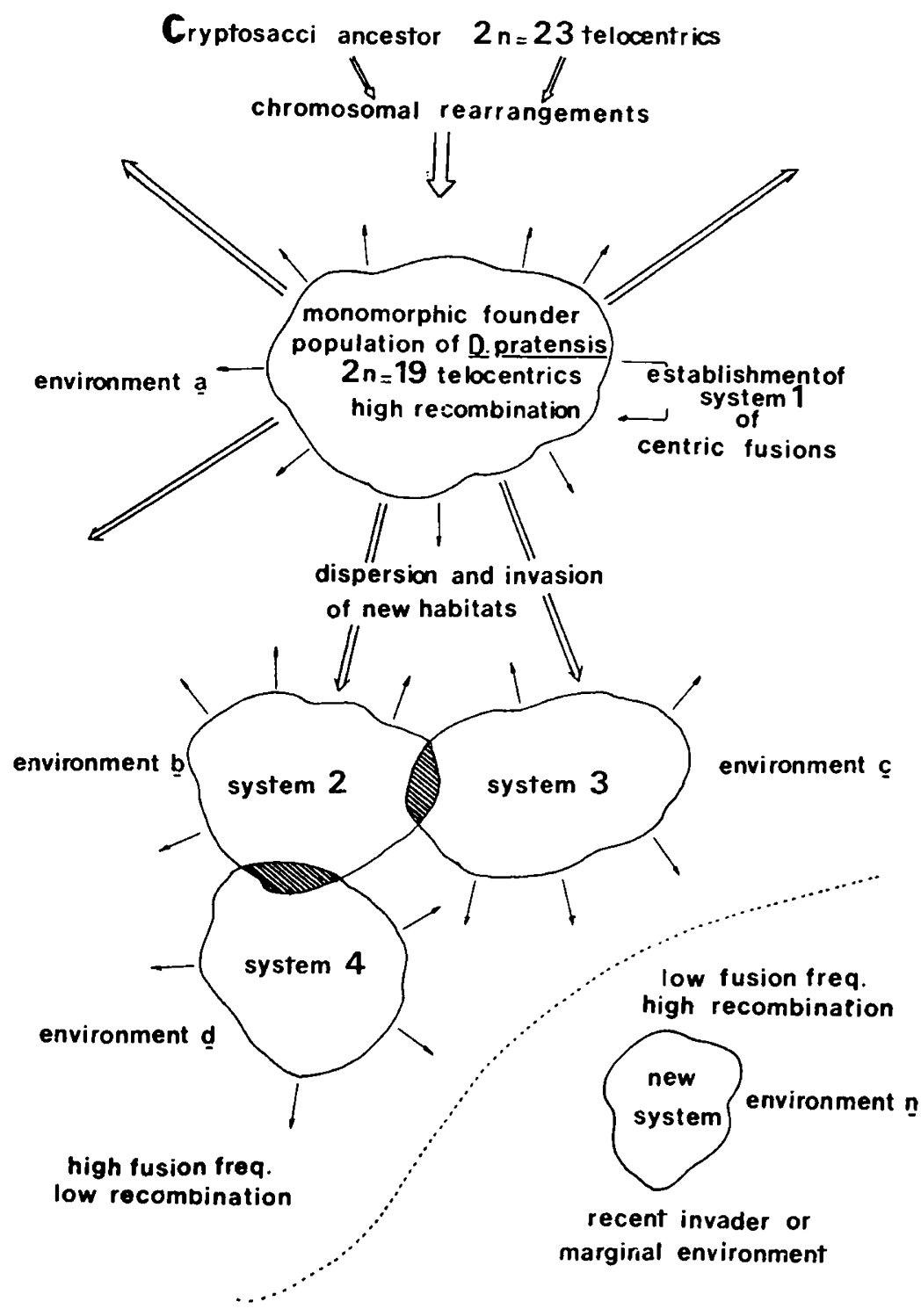

Fig 7. Model of chromosomal evolution of $D$ pratensis: dispersal occurs mainly in the standard (high recombination) form. Once a population becomes established in and adapted to a new environment, the surging of a fusion system protects adaptive supergenes (ie systems 2-4). These populations have high frequency of fusions and low recombination. Shaded areas are hybrid zones between populations having different fusion systems. Recently established populations or those in marginal environments show low frequency of fusions and high recombination potential (see text). 
are involved in different arm combinations, if populations polymorphic for metacentrics with monobrachial homologies intercross, some hybrids should form meiotic multivalents prone to non-convergent orientation and unbalanced segregation thus producing negative heterosis. The frequency of such hybrids will depend on the frequencies of monobrachially homologous metacentrics in each population. King (1987) contemplates this situation but considers that fixation is needed, which we believe is not so. In fact, in hybrid zones, the frequency of metacentrics could be boosted in order to avoid gene exchange between chromosomal races (Bidau, 1991; Tosto and Bidau, 1991). Furthermore, King (1987) says that through this interaction "neutral rearrangements have been transformed into negatively heterotic changes". The rearrangements involved are not necessarily neutral and in $D$ pratensis they certainly exert effects on recombination which may be adaptive since different supergenes may be involved (Bidau, 1990).

The interaction of polymorphic forms of $D$ pratensis would produce a certain proportion of sub-fertile hybrids. This could be interpreted as an incipient postmating mechanism that could be enhanced in principle by the fixation of the fusions in the diverging populations. Hybrids zones such as predicted have been found and analyses of hybrid meiotic behaviour and frequency of metacentrics are currently being performed (Bidau, 1991; Tosto and Bidau, 1991).

\section{ACKNOWLEDGMENTS}

The senior author wishes to express his sincere gratitude to his sons, Claudio Jr and Pablo for help in the collection of grasshoppers. Mrs R Josens was very helpful during one of the ficld trips and Miss M Korenblum karyotyped some of the La Pampa specimens. Prof Dr J H Hunziker guided and stimulated the beginnings of the senior author's research on grasshopper cytogenetics. Special thanks to Miss M Giménez for help in the preparation of this typescript. The work on $D$ pratensis has been aided by CONICET grants to Dr Hunziker and UBA grants to CJB.

\section{REFERENCES}

Baker RJ and Bickham JW (1986) Speciation by monobrachial centric fusions. Proc Natl Acad Sci USA 83, 8245-8248

Bidau CJ (1984) Estudios citogenéticos en Orthoptera de Sudamérica. PhD Thesis, Universidad de Buenos Aires.

Bidau CJ (1986) A nucleolar-organizing B chromosome showing segregationdistortion in the grasshopper Dichroplus pratensis (Melanoplinae, Acrididae). Can $J$ Genet Cytol, 28, 138-148

Bidau CJ (1987) Influence of a rare unstable B chromosome on chiasma frequency and non-haploid sperm formation in Dichroplus pratensis (Melanoplinae, Acrididae). Genetica 73, 201-210

Bidau CJ (1989) Zonas híbridas en Ortópteros: el ejemplo de Dichroplus pratensis (Acrididae). Actas I Congr Argentino Entomol (Tucumán), 109-124

Bidau CJ (1990) The complex Robertsonian system of Dichroplus pratensis (Melanoplinae, Acrididae). II. Effects of the fusion polymorphisms on chiasma frequency and distribution. Heredity 64, 145-159 
Bidau CJ (1991) Multivalents resulting from monobrachial homologies within a hybrid zone in Dichroplus pratensis (Acrididae): meiotic orientation and segregation. Heredity 66, 219-232

Bidau CJ , Hasson ER (1984) Population cytology of Leptysma argentina Bruner (Leptysminae, Acrididae). Genetica 62, 161-175

Bidau CJ, Mirol P (1988) Orientation and segregation of Robertsonian trivalents in Dichroplus pratensis (Acrididae). Genome 30, 947-955

Bogdanov YF, Kolomiets OL, Lyapunova EA, Yanina IY, Mazurova TF (1986) Synaptonemal complexes and chromosome chains in the rodent Ellobius talpinus heterozygous for ten Robertsonian translocations. Chromosoma 94, 94-102

Brussard PF (1984) Geographic patterns and environmental gradients: the centralmarginal model in Drosophila revisited. Annu Rev Ecol System 15, 25-64

Capanna E (1982) Robertsonian numerical variation in animal speciation: Mus musculus, an emblematic model. In: Mechanisms of Speciation (Barigozzi C, ed) Alan R Liss, NY, 155-177

Colombo PC (1987) Effect of centric fusions on chiasma frequency and position in Leptysma argentina. I. Spontaneous and stable polymorphic centric fusions. Genetica 72, 171-179

Garagna S, Zucotti M, Searle JB, Redi CA, Wilkinson PJ (1989) Spermatogenesis in heterozygotes for Robertsonian chromosomal rearrangements from natural populations of the common shrew, Sorex araneus. J Reprod Fertil 87, 431-438

Hewitt GM (1979) Orthoptera. In: Animal Cytogenetics 3. Insecta l (John B, ed) Gebrüder Borntraeger, Berlin

Hewitt CM, Schroeter GL (1968) Population cytology of Edaleonotus. I. The karyotypic facies of (Edaleonotus enigma. Chromosoma 25, 121-140

John B (1981) Chromosome change and evolutionary change: a critique. In: Evolution and Speciation (Atchley WR, Woodruff DS, eds) Cambridge Univ Press, 23-51

John B (1983) The role of chromosome change in the evolution of Orthopteroid insects. In: Chromosomes in the Evolution of Eukaryotes (Sharma AK, Sharma AS, eds) CRC Press, Boca Raton FL, 1-110

Jolın B, Freeman MGS (1975) Causes and consequences of Robertsonian exchange. Chromosoma 52, 123-136

John B, Hewitt GM (1968) Patterns and pathways of chromosome evolution within the Orthoptera. Chromosoma 25, 40-74

Jolnn B, Lightfoot DC, Weissman DB (1983) The meiotic behavior of natural F1 lyybrids between Trimerotropis suffusa Scudder and T cyaneipennis Benner (Orthoptera: (Edipodinae). Can J Genet Cytol 25, 467-477

John B, Weissman DB (1977) Cytogenetic components of reproductive isolation in Trimerotropis thalassica and $T$ occidentalis. Chromosoma 60, 165-186

Jones K (1977) The role of Robertsonian change in karyotype evolution in higher plants. Chromosomes Today 6, 121-129

King M (1982) A case for simultaneous multiple rearrangements. Genetica 59, 53-60 King M (1987) Chromosomal rearrangements, speciation and the theoretical approach. Heredity 59, 1-6 
Koop BF, Baker RJ, Genoways HH (1983) Numerous chromosomal polymorphisms in a natural population of rice rats (Oryzomys, Cricetidae). Cytogenet Cell Genet $35,131-135$

Lande R (1985) The fixation of chromosomal rearrangements in a subdivided population with local extinction and colonization. Heredity 54, 323-332

Levan A, Fredga K, Sandberg AA (1964) Nomenclature for centromeric position of chromosomes. Hereditas 52, 201-214

Liebermann J (1963) Contribución al conocimiento de Dichroplus pratensis Bruner (Orth, Acrid). IDIA 191, 23-28

Mayr E (1982) Processes of speciation in animals. In: Mechanisms of Speciation (Barigozzi C, ed) A R Liss NY, 1-19

Mesa A (1956) Los cromosomas de algunos acridoideos uruguayos (Orthoptera, Caelifera, Acridoidea). Agros 141, 32-45

Mesa A (1971) Cariología de tres especies de Acridios del género Dichroplus (Orthoptera, Acrididae). Rev Peru Entomol 14, 233-237

Mesa A, Ferreira A, Carbonell CS (1982) Cariología de los acridoideos neotropicales: estado actual de su conocimiento y nuevas contribuciones. Ann Soc Entomol Fr (NS) 18, 507-526

Mirol PM, Bidau CJ (1991a) Meiotic behavior of Robertsonian heterozygotes in populations of Dichroplus pratensis (Acrididae) with different fusion frequencies Genetica (in press)

Mirol PM and Bidau CJ (1991b) Proximal chiasmata induce non-disjunctional orientation of Robertsonian trivalents in a grasshopper Heredity (in press)

Nachman MW, Myers P (1989) Exceptional chromosomal mutations in a rodent population are not strongly underdominant. Proc Natl Acad Sci USA 86, 6666-6670 Patton JL, Sherwood SW (1983) Chromosome evolution and speciation in rodents. Annu Rev Ecol Syst 14, 139-158

Peters GB (1982) The recurrence of chromosome fusion in interpopulation hybrids of the grasshopper Atractomorpha similis. Chromosoma 85, 323-347

Redi CA, Capanna E (1988) Robertsonian heterozygotes in the house mouse and the fate of their germ cells. In: The Cytogenetics of Mammalian Autosomal Rearrangements. A R Liss, NY, 315-329

Redi CA, Garagna S, Capana E (1990) Nature's experiment with in situ hybridization? A hypothesis for the mechanism of Rb fusion. J Evol Biol 3, 133-137

Redi CA, Garagna S, Mazzini G, Winking H (1986) Pericentromeric heterochromatin and A-T contents during Robertsonian fusion in the house mouse. Chromosoma $94,31-35$

Reig OA (1984) Significado de los métodos citogenéticos par la distinción y la interpretación de las especies, con especial referencia a los mamíferos. Rev Mus Argent Cienc Nat 13(3), 19-44

Sáez FA (1956) Estudios citogenéticos en Ortópteros Sudamericanos: el cariotipo de 32 especies. Biologica 22, 21-26

Sáez FA, Pérez-Mosquera G (1970) Citogenética del género Dichroplus: (Orthoptera, Acrididae). Recientes Adelantos en Biologí a (Cong Argent Cienc Biol) $5,111-120$ 
Searle JB (1984) Non disjunction frequencies in Robertsonian heterozygotes from natural populations of the common shrew, Sorex araneus L. Cytogenet Cell Genet $38,265-271$

Searle JB (1988) Selection and Robertsonian variation in nature: the case of the common shrew. In: The Cytogenetics of Mammalian Autosomal Rearrangements. A R Liss, NY, 507-531

Searle JB, Hubner R, Wallace BMN, Garagna S (1990) Robertsonian variation in wild mice and shrews. Chromosomes Today 10, 253-263

Sites JW, Moritz C (1987) Chromosomal evolution and speciation revisited. Syst Zool 36(2), 153-174

Sperlich D, Pfriem P (1986) Chromosomal polymorphisms in natural and experimental populations. In: The Genetics and Biology of Drosophila. Academic Press, London, vol 3, 257-309

Tichy H, Vucak I (1987) Chromosomal polymorphism in the house mouse (Mus domesticus) of Greece and Yugoslavia. Chromosoma 95, 31-36

Tosto D (1989) Estudios citogenéticos y morfológicos en Dichroplus pratensis (Melanoplinae, Acrididae). Tesis de Licenciatura, Univ de Buenos Aires

Tosto DS, Bidau CJ (1991) Distribution of chromosome frequencies within a hybrid zone of Dichroplus pratensis (Melanoplinae, Acrididae). Heredity 67 (in press)

White MJD (1973) Animal Cytology and Evolution. Cambridge Univ Press, London, NY, 3rd edn

White MJD (1978a) Modes of Speciation. WH Freeman and Co, San Francisco

White MJD (1978b) Chain processes in chromosomal speciation. Syst Zool 27, 285298

White MJD (1982) Rectangularity, speciation and chromosome architecture. In: Mechanisms of Speciation (Barigozzi C, ed) A R Liss, NY, 75-103 